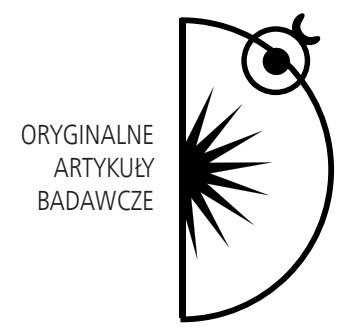

Agata Szwech

\title{
Źródła i znaczenia kompetencji coacha. Studia przypadków
}

DOI: http://dx.doi.org/10.12775/PBE.2013.015

\section{Coaching - ustalenia teoretyczne}

Coaching jest zagadnieniem związanym ze środowiskiem pracy, z rozwojem zawodowym, poradnictwem, jak również wpisuje się w obszar edukacji jako metoda stymulowania rozwoju kompetencji i umiejętności jednostki ${ }^{1}$. W literaturze przedmiotu poświęconej coachingowi, dominują dwa obszary jego analizy: teoria zarządzania oraz psychologia. $\mathrm{W}$ obu podejściach elementem wspólnym jest procesualne nastawienie na zmianę, rozwój człowieka. Podejście coachingowe w zarządzaniu zakłada koncentrację profesjonalnie przygotowanego specjalisty na planowaniu pracy w zespołach. Z kolei psychologowie skupiają się na odbiorcach działań coachingowych. Sposób prowadzenia coachingu jest uzależniony od wybranej przez prowadzącego koncepcji psychologicznej². Jednak w miarę zwiększania się liczby szkół coachingu w Polsce, które realizują szkolenia zgodne ze standardami międzynarodowymi (ICC, ICF i inne), coaching zyskał inne znaczenie. Zaczął reprezentować postawę życiową, podejście do drugiego człowieka, w którym obowiązują pewne bazowe za-

${ }^{1}$ E. Dębska, Mentor, coach, facylitator - trzy role doradcy zawodu, w: „Edukacja Dorosłych” 2010, nr 1, s. 77.

${ }^{2}$ Tamże, s. 81-82. 
sady sprawiające, że coaching stał się formą wspierania drugiego człowieka, inną od instruowania, treningu, nauczania, psychoterapii, doradztwa, mentoring czy konsultingu ${ }^{3}$.

Metoda coachingu budzi liczne kontrowersje, ale prace naukowe nad nią nie ustają. Przy Uniwersytecie Harwardzkim powstał Instytut Coachingu, który zajmuje się m.in. przyznawaniem grantów na badania naukowe w tej dziedzinie.

\section{Rola coacha}

Coaching jest procesem opartym na partnerskiej relacji między coachem a osobą coachowaną. Jednak to klient pełni ważniejszą rolę podczas tego procesu, to on posiada możliwości, potencjał i moc, aby dokonać zmiany, i to klient ponosi całą odpowiedzialność za wynik coachingu. Nasuwa się więc pytanie: jaka jest rola coacha, skoro wszystko robi „coachowany”? Z analizy dostępnych źródeł można stwierdzić, że coach przede wszystkim jest, ale również wierzy w klienta, pomaga ustalić cele coachingu (długofalowe i bieżące), zadaje pytania, wspiera „coachowanego" w procesie organizowania myśli, wyciągania wniosków, pilnuje procesu dochodzenia do celu, prowadzi „,coachowanego” ku doświadczeniom. Przekazuje klientowi informację zwrotną na podstawie zaobserwowanych zachowań. Stawia wyzwania klientowi, tak by mógł on ocenić swoje umiejętności. Można powiedzieć, że coach jest swoistą siłą wspierającą rozwój człowieka i jego podążanie przez życie w zgodzie z posiadanymi przez niego umiejętnościami i predyspozycjami. Dokonuje tego, stosując różne podejścia, techniki, zadania ${ }^{4}$.

Jabłonowska (za Holliday) zwraca uwagę, że do zasad, którymi powinien kierować się perfekcyjny coach, należą: jasność w komunikowaniu intencji, cierpliwość, zaangażowanie, poufność, tworzenie poczucia pewności pracownika, współdziałanie z nim, zgoda na popełnianie przez niego błędów i podejmowanie ryzyka, unikanie etykietowania, szacunek okazywany pracownikowi. Jednocześnie coach nie prowadzi terapii psychologicznej, nie koncentruje się na redukcji psychicznego bólu ani na niesieniu pomocy w problemach psychicznych lub emocjonalnych ${ }^{5}$. Thorpe i Clifford, autorzy Podręcznika coachingu, wskazują, że coach, aby efektywnie prowadzić coaching, musi rozwinąć kil-

${ }^{3}$ M. Zubrzycka-Nowak, K. Rybczyńska, S. Monostori, Czym (nie) jest coaching, Sopot 2010, s. 12 .

${ }^{4}$ Tamże, s. $12-13$.

${ }^{5}$ L. Jabłonowska, Coaching jako forma rozwoju kompetencji pracownika, w: Z. P. Kruszewski (red.), Możliwości i ograniczenia ksztatcenia ustawicznego, Płock 2008, s. 114. 
ka podstawowych umiejętności, takich jak: planowanie i zarządzanie czasem, analityczną interpretację, negocjowanie, nawiązywanie kontaktu, udzielanie informacji zwrotnej, aktywne słuchanie, zadawanie pytań, co wiąże się ze zdobywaniem informacji potrzebnych w procesie coachingu, obserwację, pomaganie klientowi w uczeniu się i rozwijaniu nowych umiejętności przez wyznaczanie celów i ocenę ich realizacji ${ }^{6}$. Ważne jest także, aby coach posiadał wiedzę z zakresu uczenia się ludzi dorosłych, pomocną w wyborze kierunku działania podczas prowadzenia rozmów coachingowych.

\section{Formalna, pozaformalna i nieformalna edukacja dorosłych jako źródła wiedzy coachingowej}

Jak uważa Malewski, termin „edukacja” stereotypowo wartościujemy dodatnio, ponieważ z edukacją łączymy nadzieję na poznanie, mądrość i rozwój. Edukacja nie tylko poszerza naszą zdolność postrzegania i rozumienia świata, wspomaga indywidualny rozwój, wyposaża w kompetencje pozwalające radzić sobie ze światem, własnym życiem w świecie, ale także w równym stopniu zamyka nasze poznanie, wyznacza pułapy „wystarczającego” rozwoju ${ }^{7}$ Na tej podstawie można stwierdzić, iż edukacja dorosłych jest zjawiskiem wielowymiarowym, jednak Kargul zauważa, że tradycyjne miejsca zdobywania przez człowieka wiedzy i umiejętności zostały zanegowane przez współczesność, a dotychczasowe systemy edukacyjne nie są w stanie sprostać wszystkim potrzebom edukacyjnym ${ }^{8}$. W tym ujęciu „edukacja dorosłych oznacza całościowe ujęcie procesów szkoleniowych, zarówno formalnych jak i nieformalnych, gdzie ludzie uważani za dorosłych przez społeczeństwo, do którego należą, rozwijają swoje zdolności, wzbogacają wiedzę i doskonalą techniczne i zawodowe kwalifikacje lub nadają im nowy kierunek, aby zaspokoić własne potrzeby lub te, które są istotne z punktu widzenia społeczeństwa. Uczenie się dorosłych dotyczy zarówno formalnego, jak i dalszego kształcenia oraz spektrum edukacji nieformalnej dla uczącego się społeczeństwa" .

\footnotetext{
${ }^{6}$ S. Thorpe, J. Clifford, The Coaching Handbook: An Action Kit for Trainers and Managers, London 2003, s. 44.

${ }^{7}$ M. Malewski, Modele pracy edukacyjnej z ludźmi dorostymi, w: E. Przybylska (red.), Andragogiczne wątki, poszukiwania, fascynacje, Torun 2001, s. 287.

${ }^{8}$ J. Kargul, Obszary pozaformalnej i nieformalnej edukacji dorostych, Wrocław 2001, s. 7.

${ }^{9}$ J. Półturzycki, Kierunki i tendencje przemian wspótczesnej edukacji dorostych, w: J. Sarana (red.), Edukacja dorostych. Teoria i praktyka w okresie przemian, Lublin 2000, s. 21.
} 
Odnosząc te rozważania do zawodu coacha, Czarkowska pisze, że zakres teoretycznej wiedzy potrzebnej do wykonywania profesji coacha jest niezwykle szeroki i ciągle otwarty. Aby skutecznie prowadzić proces coachingowy, coach absolutnie nie musi być ekspertem w branży klienta, powinien natomiast posiadać szeroką wiedzę z zakresu nauk humanistyczno-społecznych ${ }^{10}$. Coaching odwołuje się do wielu różnych dziedzin nauki, zwłaszcza psychologii, socjologii, antropologii, nauk o zarządzaniu, rozwoju i przywództwie. Pośród wielu inspiracji teoretycznych, użytecznych w coachingu, można wyliczyć teorie uczenia się, rozwoju osób dorosłych, andragogikę, teorie zmiany, teorie inteligencji emocjonalnej, inteligencji społecznej i duchowej, myślenie systemowe, hipnozę czy teorię chaosu ${ }^{11}$. Przy tak szerokim spektrum wiedzy akademickiej edukacja coacha jawi się jako nieustanny proces zdobywania kompetencji zawodowych, takich jak wiedza, umiejętności, postawy, oraz poszerzania informacji, których stosowanie może pomóc w pracy z klientem.

Nasuwa się więc pytanie, jakie formy edukacji dominują i jakie są najbardziej preferowane wśród osób zajmujących się coachingiem. Czy jest to edukacja formalna (szkolna) dorosłych, oparta na systematycznym przekazie wiedzy, umiejętności i postaw w ustalonym miejscu i czasie, której celem jest uzyskanie formalnych kwalifikacji potwierdzonych świadectwami i dyplomami? ${ }^{12} \mathrm{Czy}$ też edukacja pozaformalna (pozaszkolna) dorosłych, obejmująca każdą zorganizowaną działalność edukacyjną odbywającą się poza formalnym systemem oświatowym, podejmowaną samodzielnie bądź w ramach jakiejś szerszej aktywności społecznej, jako jej ważny składnik? ${ }^{13}$ A może edukacja nieformalna (incydentalna) dorosłych, która jest „prawdziwie całożyciowym procesem, w którym jednostka przyswaja postawy, wartości, umiejętności i wiedzę z powszechnego doświadczenia oraz zasobów i wpływów środowiska życia"? ${ }^{14}$

W środowisku branżowym coachów pojawiły się już raporty, które prezentują, ile jest szkół coachingu na polskim rynku, jakie są ich oferty edukacyjne oraz jakimi kryteriami należy kierować się przy wyborze szkoły najlepszej z punktu widzenia indywidualnych potrzeb. Jednym z takich raportów jest Szkoła dla coacha Kołodkiewicz, gdzie czytamy, iż „oprócz formalnego wykształcenia

${ }^{10}$ L. D. Czarkowska, Profesjonalizm i proces profesjonalizacji w coachingu, „Coaching Review” 2010, nr 1, s. 44-45.

${ }^{11} \mathrm{http}: / /$ www.pdf.net/Files/Dublin\%20Declaration\%20on\%20Coaching.pdf(dostęp: 17.02.2011).

${ }_{12}$ R. Pachociński, Andragogika w ujęciu międzynarodowym, Warszawa 1998, s. 17.

${ }_{13}^{13}$ J. Lowe, Rozwój oświaty dorostych, Warszawa 1982, s. 31.

${ }^{14} \mathrm{M}$. Malewski, Od nauczania do uczenia się. O paradygmatycznej zmianie w andragogice, Wrocław 2010, s. 21. 
zdobytego w szkołach i na kursach coachingu, istnieją również inne formy zdobywania coachingowych »szlifów«. Jednym z nich jest szkolenie wewnętrzne kształtujące coachów firmowych, oparte zwykle na konkretnym modelu lub metodzie zatwierdzonej korporacyjnie i obowiązującej w całej firmie lub jej części. Innym sposobem jest edukacja »intuicyjna«, oparta na samodzielnie nabieranych umiejętnościach, lekturze, wcześniejszych doświadczeniach, czasem wiedzy psychologicznej. Coachowie wywodzący się z tej grupy bazują na wcześniejszej praktyce. Coachowie ci coraz chętniej zgłaszają się na szkolenia, żeby usystematyzować wiedzę i zdobyć formalne potwierdzenie swoich umiejętności”" ${ }^{15}$. Bez względu na różnorodność motywacji znaczenie formalnego wykształcenia dla jakości i profesjonalizmu usług wydaje się być oczywiste, co nie zmienia faktu, że samo szkolenie czy nawet najbardziej renomowana szkoła nie wystarczą, żeby stać się skutecznym i efektywnym coachem ${ }^{16}$.

\section{Ramy metodologiczne badania}

Celem przeprowadzonych przeze mnie badań jest opis źródeł pozyskiwania wiedzy, umiejętności i postaw przez osoby zajmujących się zawodowo coachingiem. W celu uzyskania tych informacji przedmiotem poznania uczyniłam narracje biograficzne praktykujących coachów, w których opisywali, w jaki sposób zdobywali kompetencje (przez które rozumiem wiedzę, umiejętności oraz motywację warunkujące zachowania, które umożliwiają realizację zadań zawodowych zgodnie $\mathrm{z}$ oczekiwaniami ${ }^{17}$ ) potrzebne w coachingu.

Badania własne skoncentrowałam na pytaniach o:

- przyczyny zainteresowania coachingiem i podążenia tą ścieżką realizacji zawodowej („Dlaczego Pan/Pani została coachem?”),

- źródła pozyskiwania umiejętności i wiedzy dotyczącej coachingu oraz sposoby doskonalenia się w tej profesji (,Skąd czerpał Pan/Pani wiedzę na temat coachingu i w jaki sposób doskonalił się Pan/Pani w tej dziedzinie?"),

- refleksję na temat znaczenia, jakie odgrywają wiedza, umiejętności i wartości w pracy coacha, a także dla procesu coachingu (,Jaką rolę pełnią wiedza, umiejętności, postawy/wartości w pracy coacha?”).

\footnotetext{
${ }^{15} \mathrm{http}: / /$ www.pifs.org.pl/pliki/raport\%20szkola\%20dla\%20coacha.pdf (dostęp: 17.02.2011).

16 Tamże.

${ }^{17}$ G. Filipowicz, Zarządzanie kompetencjami zawodowymi, Warszawa 2004, s. 26.
} 
W badaniach wykorzystałam metodę biograficzną, której specyficzną cechą, jako badań osadzonych w strategii jakościowej, jest wyprowadzanie hipotez dopiero po przeprowadzonym badaniu. Problemy formułuje się w postaci ogólnych pytań i zgodnie z zasadą otwartości, na której opierają się badania biograficzne, rezygnuje się z hipotez wstępnych. Lasocińska, charakteryzując metodę biograficzną, pisze, że jej przedmiotem zainteresowania jest przebieg życia danej jednostki, który ukazuje jej aktywność, np. życie zawodowe. Istotna w badaniach biograficznych jest indywidualna i symboliczna interpretacja rzeczywistości ${ }^{18}$. Uwzględnienie owego subiektywnego punktu widzenia respondentów w badaniach jest znaczącym wyróżnikiem metody biograficznej ${ }^{19}$.

Badania prowadzono za pomocą techniki wywiadu narracyjnego indywidualnego częściowo kierowanego. Badani byli proszeni o opowiedzenie fragmentu własnej historii życia, w tym przypadku zawodowego. Respondenci rekonstruowali swoje doświadczenia związane ze zdobywaniem nowych umiejętności, postaw i wiedzy we własny, indywidualny sposób. Technika ta pozwoliła pokazać rzeczywistość z perspektywy indywidualnych przeżyć. W badaniach zastosowano celowy dobór próby badawczej, uzasadniony rodzajem podejmowanej problematyki badawczej. Badaniu zostało poddanych troje praktykujących coachów.

Istotne dla przedstawienia biografii zawodowych okazało się wykorzystanie studium indywidualnego przypadku, które jest rodzajem rekonstrukcji i interpretacji pewnego fragmentu życia ludzkiego, opartego na określonych materiałach dowodowych, w tym wypadku spisanych narracjach badanych osób. Studium przypadku traktuję tu jako formę porządkowania i reprezentacji informacji o określonej osobie oraz jej doświadczeniach, konstruowaną w oparciu o technikę wywiadu: narracyjnego $\mathrm{w}$ formie i biograficznego w treści ${ }^{20}$. Zgromadzone narracje biograficzne złożyły się na surowy materiał, który poddano analizie.

Analiza danych jakościowych jest procesem polegającym na przekształcaniu uzyskanych $\mathrm{w}$ trakcie badania danych $\mathrm{w}$ postaci tekstu w teorię ugruntowaną. Teoria ta powstaje w wyniku uporządkowania i zweryfikowania tekstu surowego. Analiza tekstu podstawowego przebiegała zgodnie z metodologią za-

\footnotetext{
${ }^{18}$ K. Lasocińska, Badania biograficzne twórców. Rola twórczości w ksztattowaniu życia, w: K. J. Szmidt (red.), Metody pedagogicznych badań nad twórczościa, Łódź 2009, s. 111.

${ }^{19}$ D. Lalak, Życie jako biografia. Podejście biograficzne w perspektywie pedagogicznej, Warszawa 2010 , s. 238-239.

${ }^{20}$ M. Piorunek, Bieg życia zawodowego. Kontekst transformacji kulturowych, Poznań 2009, s. 68 .
} 
proponowaną przez Rubachę w trzech etapach: redukcji danych - kodowaniu, reprezentacji danych i ich weryfikacji. Wymienione rodzaje analizy zazębiają się w modelu kołowym, przeplatają, są postępujące i wsteczne zarazem. Nakładanie się tych czynności na siebie wynika z konieczności ciągłego odnoszenia danych do kontekstu, po to, aby zbudować teorię ugruntowaną właśnie na danych umieszczonych w kontekście ${ }^{21}$.

Zgodnie z terminologią zaproponowaną przez Rubachę, redukcja danych polega na ich kodowaniu. Kodowanie to wyszukiwanie i etykietowanie w tekście kategorii analitycznych oraz nadawanie im znaczenia ${ }^{22}$. Zgodnie $\mathrm{z}$ tą definicją należy nie tylko nazwać kategorie, ale także nadać im znaczenie. W tym celu zastosowane zostało kodowanie zogniskowane, które opisuje kategorie ze względu na pięć ognisk: 1) warunki przyczynowe (interakcje, zdarzenia, które bezpośrednio poprzedziły wystąpienie zachowania opisanego w kategorii analitycznej), 2) kontekst (bezpośrednie warunki towarzyszące zjawisku, występujące równolegle), 3) warunki interweniujące (strukturalne czynniki wpływające na realizację celów działania, przyczyniające się do zidentyfikowanego przebiegu zjawiska), 4) działania (to, co robią badani w danej sytuacji w ramach warunków interweniujących), 5) konsekwencje (doświadczone przez badanych rezultaty działań, które prowadzą badacza do nowych kategorii ${ }^{23}$. Następnie przechodzi się do kodowania teoretycznego, które polega na formułowaniu hipotetycznych wyjaśnień dotyczących zależności między wyselekcjonowanymi kategoriami. Wyjaśnienia hipotetyczne to inaczej kody teoretyczne stanowiące podstawę formułowania not teoretycznych, które tworzą teorię ugruntowaną ${ }^{24}$. Kolejnym etapem w omawianej procedurze badawczej jest kodowanie selektywne, w którym spośród opisanych kategorii wybiera się bezpośrednio dotyczące problemu badań. Kategorie te są podstawą dla dalszego etapu analizy, czyli reprezentacji danych ${ }^{25}$.

Po zakończeniu kodowania możemy przejść do drugiego etapu analizy reprezentacji danych. Procedura ta zmierza do zestawienia kodów w celu zbudowania teorii ugruntowanej. Wyróżnia się trzy grupy metod reprezentacji danych: sekwencyjną analizę dyskursu, sekwencyjną analizę danych oraz szacowanie współwystępowania ${ }^{26}$. Uzyskane $\mathrm{z}$ badania dane pozwalają na prze-

\footnotetext{
${ }^{21}$ K. Rubacha, Metodologia badań nad edukacją, Warszawa 2008, s. 259-260.

22 Tamże, s. 263.

${ }^{23}$ Tamże, s. 265.

${ }^{24}$ Tamże, s. 264.

${ }^{25}$ Tamże, s. 274.

${ }^{26}$ Tamże, s. 275.
} 
prowadzenie szacowania współwystępowania, które polega na wykrywaniu prawidłowości w poszczególnych sekwencjach danych. Działanie to miało na celu zaprojektowanie sieci powiązań przyczynowych pomiędzy badanymi kategoriami ${ }^{27}$.

W artykule prezentuję wyniki reprezentacji sieci powiązań, które posłużyły do sformułowania teorii ugruntowanej $\mathrm{w}$ danych, tworzonej oddolnie na podstawie analizy tekstów surowych, zawierających fakty i kontekst ${ }^{28}$. Składa się ona z hipotetycznych twierdzeń, które należy zweryfikować. Weryfikacja materiału badawczego była wynikiem jego konfrontacji z literaturą przedmiotu, co stanowiło ostatni etap analizy danych.

\section{Analiza i interpretacja wyników badań}

W prezentowanych badaniach uczestniczyło troje praktykujących coachów: Krystyna, Tomasz i Mariusz. Wypowiedzi wszystkich badanych nagrywano. Spotkania trwały około godziny. Rozmowy przeprowadzano w okresie od kwietnia 2012 r. do maja 2012 r.

Wykresy 1-9 przedstawiają regularności zachodzące pomiędzy kategoriami dotyczącymi zainteresowania coachingiem oraz źródeł, z jakich korzystali badani w celu nabycia wiedzy, umiejętności i postaw potrzebnych do wykonywania profesji coacha.

\section{Reprezentacje sieci powiązań: zainteresowanie coachingiem}

Prezentowane wykresy ukazują trzy sieci powiązań przyczynowych pomiędzy badanymi kategoriami w wywiadach coachów, Krystyny, Tomasza i Mariusza, odnoszącymi się do problemu badawczego ,zainteresowanie coachingiem”.

27 Tamże.

${ }^{28}$ Tamże, s. 259. 
Wykres 1. Sieć powiązań wywiadu 1 (Krystyna)

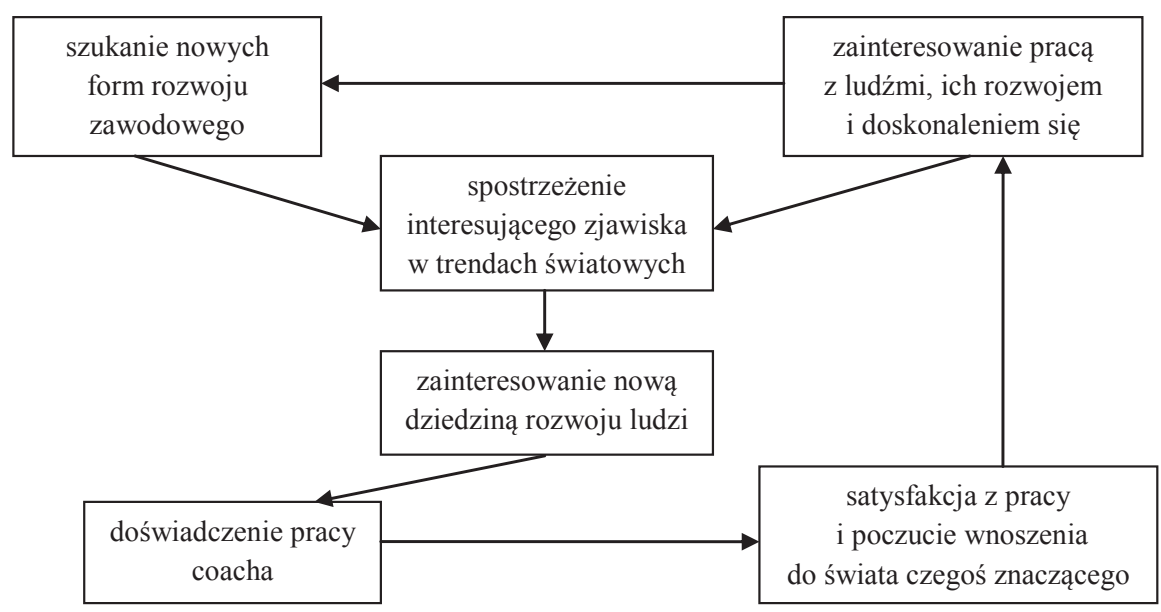

Źródło: badania własne.

Nota 1: Respondentka wykonuje zawód związany z kierowaniem rozwojem osobistym, który odpowiada jej zainteresowaniu pracą z ludźmi. Poczucie satysfakcji czerpane z aktywności zawodowej skłoniło ją do doskonalenia swoich umiejętności, poszukiwania nowych metod wspierania klientów. Badana śledziła najnowsze trendy w swojej dziedzinie zawodowej i trafiła na metodę pracy z klientem rozwijającą się za granicą - coaching. Nowa profesja odpowiada badanej pod względem charakteru aktywności zawodowej, dostarcza szerokiego spektrum możliwości działania. Z racji swej różnorodności posługiwanie się przez respondentkę metodą coachingową daje jej dużo satysfakcji oraz poczucie sprawstwa, co motywuje ją do dalszego doskonalenia się i wykonywania profesji coacha. 
Wykres 2. Sieć powiązań wywiadu 2 (Tomasz)

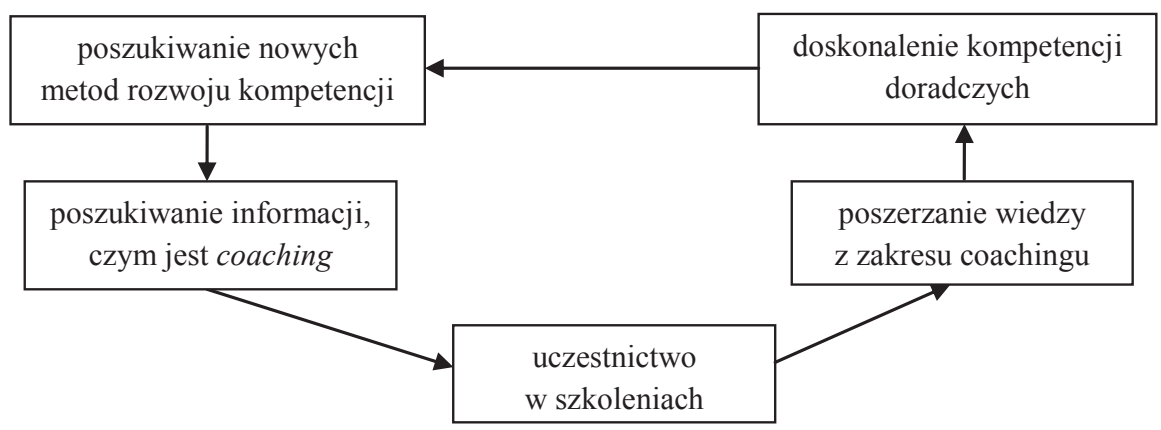

Źródło: badania własne.

Nota 2: Badany, chcąc doskonalić posiadane kompetencje doradcy zawodowego, poszukiwał nowych form rozwoju, nowych obszarów wiedzy, które wzbogacą jego warsztat i zainspirują go do bardziej efektywnego pomagania innym w odnajdywaniu ich własnej drogi zawodowej. W ramach tych poszukiwań zetknął się z coachingiem, który okazał się odpowiadać jego oczekiwaniom i potrzebom rozwoju kompetencji zawodowych. Dzięki uczestnictwu w szkoleniach poświęconych tematyce coachingu Tomasz poszerzył swoją wiedzę z tej tematyki i zaczął wprowadzać elementy coachingu do pracy doradcy zawodowego.

Wykres 3. Sieć powiązań wywiadu 3 (Mariusz)

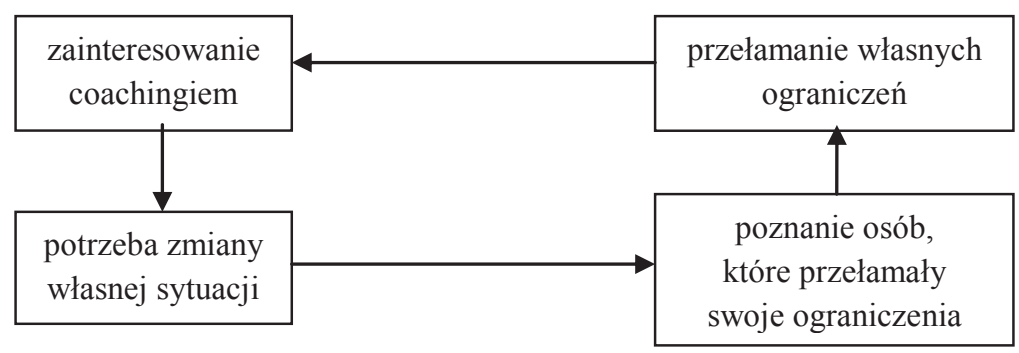

Źródło: badania własne.

Nota 3: Mariusza zainteresowanie coachingiem wyniknęło z trajektorii (sytuacja graniczna, w czasie której osoba traci kontrolę nad działaniem, orientacją w swoich odczuciach, bądź doświadcza przykrych doznań), jakiej doświadczył 
w swoim życiu. Przeżycie to stało się dla badanego bodźcem do wprowadzenia zmiany w dotychczasowym życiu. Mariusz spotkał w momencie przeżywania swojej trajektorii wartościowych ludzi pełnych pasji, którzy własnym przykładem, jak uważa, pokazali mu, jak inaczej spojrzeć na doświadczane problemy. Badany odnalazł nową pasję w życiu - coaching, który pomógł mu przełamać jego ograniczenia.

W notach teoretycznych dotyczących zainteresowania coachingiem zauważyłam zbieżność z uwarunkowaniami wynikającymi z rozwoju zawodowego, opisywanego w literaturze przedmiotu. W przypadku Krystyny i Tomasza zainteresowanie nowym obszarem aktywności zawodowej zostało spowodowane potrzebą rozwoju zawodowego, podnoszenia wiedzy i kompetencji oraz zdobywania nowych umiejętności. Takie zachowania wynikają z następstwa, jakie niesie ze sobą realizowanie zadań zawodowych. Motywacją badanych do poszerzania swojej wiedzy i kwalifikacji były własne zainteresowania, aspiracje zawodowe, posiadane zdolności, poszukiwanie nowych metod rozwoju kompetencji, potrzeba samokształcenia. Krystyna i Tomasz poszukiwali nowych sposobów rozwoju, ponieważ chcieli lepiej wykonywać swoją pracę, pasjonowała ich praca z ludźmi, ich rozwój i doskonalenie się. Istotne jest także, że badani w krótkim czasie od zapoznania się z nową metodą pracy z ludźmi zainteresowali się nią, a w miarę zagłębiania się w jej arkana stwierdzili, że odpowiada ich potrzebom zawodowym, i wykorzystywali coaching do realizacji zadań zawodowych (praca doradcy). Świadczy to o unikalności i odmienności coachingu jako metody wspierania rozwoju.

W przypadku Krystyny i Tomasza widoczna jest różnica w aspektach, na jakie kładą nacisk w swej pracy zawodowej. Dla Krystyny ważna jest satysfakcja z wykonywanej pracy, która daje jej poczucie wnoszenia do świata czegoś znaczącego. Natomiast dla Tomasza istotna jest efektywność w wykonywanej pracy, czyli praktyczny wymiar działań zawodowych.

Zainteresowanie coachingiem u trzeciego badanego wyniknęło z innych pobudek niż w przypadku Krystyny i Tomasza. Mariusz dokonał zmiany zainteresowań zawodowych w wyniku doświadczenia destabilizacji sytuacji życiowej. Pod wpływem krytycznych sytuacji, jakie zaszły w życiu badanego i w jego orientacjach wobec siebie samego, pojawiła się konieczność radykalnego przedefiniowania sytuacji życiowej. W życiu Mariusza nastąpiła faza teoretycznych wyjaśnień i prób zrozumienia własnego doświadczenia i towarzyszącego mu cierpienia. W efekcie tych przemyśleń doszło do głębokiej solidarności $\mathrm{z}$ osobami o podobnych przeżyciach, którym jednak udało się wybrnąć z trud- 
nej ${ }^{29}$. Badany silnie zidentyfikował się z ludźmi zajmującymi się coachingiem oraz organizującymi szkolenia $\mathrm{z}$ tej tematyki. Mariusz podkreślał w swojej narracji, że uczestnictwo w szkoleniach stało się w pewnym sensie stylem jego życia. Lubi atmosferę, jaka panuje podczas szkoleń, oraz ludzi, którzy w nich uczestniczą.

\section{Reprezentacje sieci powiązań: zdobywanie wiedzy i umiejętności coachingowych}

Prezentowane wykresy ukazują trzy sieci powiązań przyczynowych pomiędzy badanymi kategoriami w wywiadach coachów, Krystyny, Tomasza i Mariusza, odnoszącymi się do problemu badawczego „zdobywanie wiedzy i umiejętności coachingowych".

Wykres 4. Sieć powiązań wywiadu 1 (Krystyna)

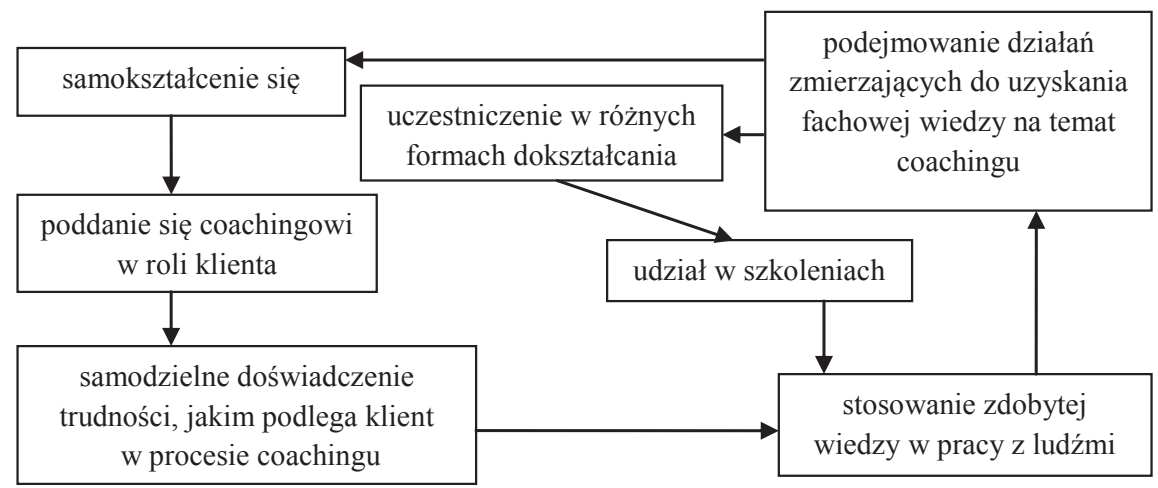

Źródło: badania własne.

Nota 4: Aby profesjonalnie i skutecznie zajmować się coachingiem, Krystyna musi zgłębiać fachową wiedzę $\mathrm{w}$ tym obszarze. Według badanej, profesjonalne wykonywanie pracy coacha wiąże się z posiadaniem wiedzy teoretycznej oraz praktycznym wykorzystaniem jej w pracy z klientami. Badana w dużej mierze zdobywa wiedzę z zakresu coachingu w wyniku samokształcenia. Krystyna uczestniczy w szkoleniach, bierze udział w warsztatach, seminariach lub konferencjach na temat coachingu. Jak podkreśla badana, wiedza teoretyczna

${ }^{29}$ K. Gajek, Biograficzna praca nad trajektoria jako sposób zdefiniowania tożsamości, w: E. Dubas (red.), Uczenie się z (własnej) biografii, Łódź 2011, s. 46. 
jest bazą do prowadzenia coachingów, jednak najwięcej coach uczy się, wykorzystując tę wiedzę w pracy z klientem. Aby efektywniej pomagać klientom, konieczne jest poddanie się coachingowi, co też respondentka uczyniła. Dzięki temu samodzielnie można doświadczyć trudności, jakim podlega klient, przechodząc proces coachingu.

Wykres 5. Sieć powiązań wywiadu 2 (Tomasz)

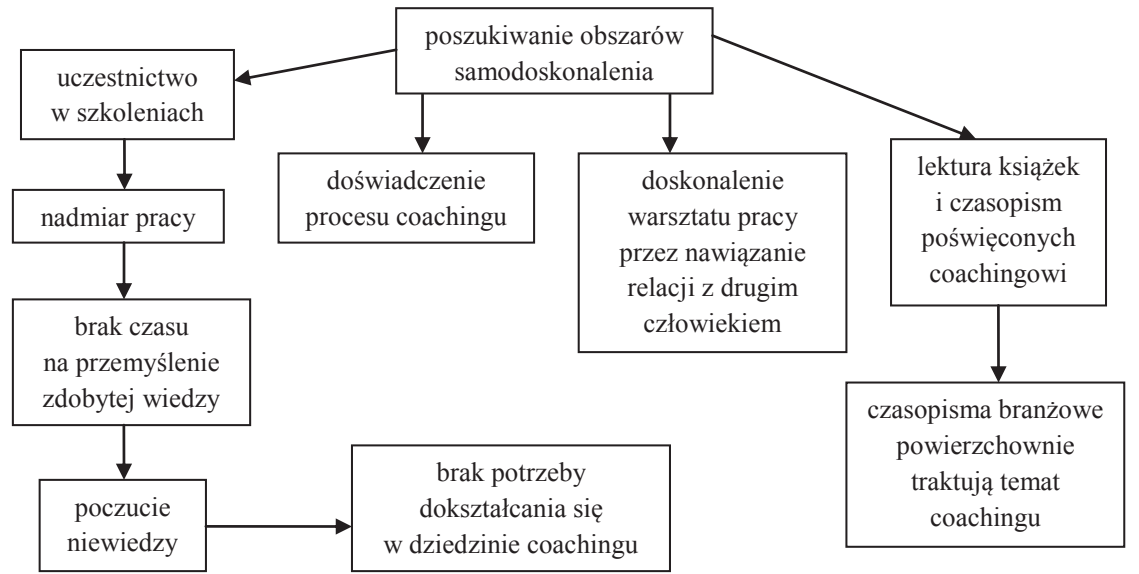

Źródło: badania własne.

Nota 5: Badany podkreśla, że podstawowym zasobem, na którym pracuje coach, jest człowiek, dlatego doskonalenie warsztatu pracy powinno odbywać się głównie przez nawiązywanie kontaktu z drugim człowiekiem, czyli przez praktykę przejawiającą się prowadzeniem sesji w roli coacha, a także poddawanie się coachingowi - stając się klientem innego coacha. Zdaniem Tomasza ważna jest także wiedza teoretyczna, którą badany zgłębia przez lekturę książek czy czasopism poświęconych coachingowi. Według Tomasza czasopisma branżowe powierzchownie traktują tematykę, której dotyczą.

Badany często korzystał również ze szkoleń poświęconych tematyce coachingu. Podkreśla on, iż jest istotne, aby nie obciążać się w krótkim czasie zbyt dużą ilością wiedzy dotyczącej jednego zagadnienia, ponieważ może zabraknąć czasu na refleksję. Jeżeli zostanie przyjęte zbyt szybkie tempo pracy, może ono doprowadzić do przeciwnego skutku - poczucia przeciążenia informacjami i niewiedzy, co znów może skutkować zniechęceniem do dalszego rozwoju w tym obszarze, jak miało to miejsce w przypadku badanego. 
Wykres 6. Sieć powiązań wywiadu 3 (Mariusz)

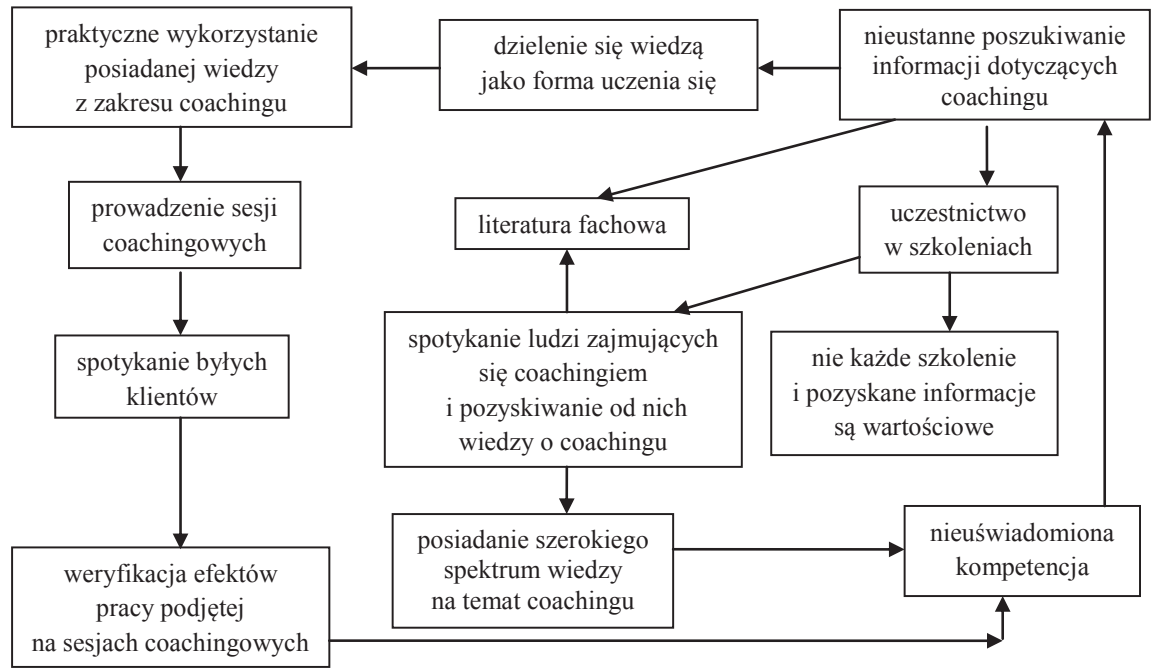

Źródło: badania własne.

Nota 6: Mariusz, bazując na własnym doświadczeniu, zauważa, iż wiedzy coachingowej oraz źródeł jej zdobywania jest bardzo wiele, dlatego badany próbuje zbudować $\mathrm{w}$ sobie krytyczne podejście do proponowanych pod hasłem coaching treści, gdyż nie każda z nich jest wartościowa. $Z$ racji wielości zagadnień i rodzajów coachingu, dobrze jest znaleźć własny obszar, w którym coach czuje się najlepiej, i skupić się na nim w swej pracy. Najczęściej badany korzysta ze szkoleń, na których poznaje ludzi zajmujących się lub interesujących się coachingiem. Takie spotkania umożliwiają badanemu wymianę poglądów i opinii. Podczas rozmów z osobami poznanymi na szkoleniach $\mathrm{z}$ coachingu Mariusz pozyskuje informacje dotyczące tego zagadnienia. Badany zdobywa wiedzę o coachingu także dzięki lekture książek poświęconych tej tematyce.

Według badanego, istotne w zdobywaniu i weryfikowaniu kompetencji coachingowych jest praktyczne wykorzystanie posiadanej wiedzy podczas prowadzenia sesji coachingowych. Badany ceni sobie także rozmowy z osobami, które korzystały z coachingu. Uzyskuje dzięki nim informację zwrotną na temat sposobu prowadzenia przez siebie coachingu oraz skuteczności zastosowanych narzędzi. Praktyczne wykorzystanie posiadanych umiejętności i wiedzy prowadzi badanego do intuicyjnej pracy z klientem, bez konieczności zastanawiania się nad wyborem właściwych dla danego klienta narzędzi pracy. 
Wnioski, jakie można wyprowadzić z not teoretycznych dotyczących zdobywania wiedzy i umiejętności coachingowych, są podobne u wszystkich badanych coachów. Krystyna, Tomasz i Mariusz uważają, iż profesjonalne i skuteczne prowadzenie coachingów wymaga posiadania fachowej wiedzy na temat metod stosowanych $\mathrm{w}$ coachingu oraz wykorzystania tej wiedzy w pracy z klientami, czyli przez praktykę. Badani przeze mnie coachowie zdobywali swoje kompetencje bez formalnego wykształcenia coachingowego, opierając swoje usługi na formowaniu umiejętności przez uczestnictwo w szkoleniach, lekturę literatury fachowej i prasy poświęconej tematyce coachingu, wcześniejsze doświadczenia zawodowe, czasem wiedzę psychologiczną. Wynika z tego, że bazą dla wiedzy i kwalifikacji stała się wieloletnia praktyka i właśnie ten element coachowie oferują klientom jako najwartościowszy ${ }^{30}$. Dla Mariusza prowadzenie sesji coachingowych, praca z klientem pozwala intuicyjnie dopasować odpowiednie narzędzia do potrzeb danego klienta, a co za tym idzie, jest kluczem do osiągnięcia mistrzostwa w swej pracy.

Tomasz podkreśla, że duże znaczenie ma refleksja nad własną praktyką, Mariusz akcentuje znaczenie krytycznej oceny własnego sposobu pracy oraz realistycznego spojrzenia na sposób nawiązywania i podtrzymywania kontaktu z klientem, a także rozumienia jego świata. Mariusz zaznacza, że coaching ma służyć klientowi, dlatego wszystko, co czyni coach, powinno być ukierunkowane na wspieranie klienta w realizacji wybranych przez niego celów. Ceni sobie rozmowy z osobami korzystającymi z coachingu, dzięki którym otrzymuje informację zwrotną o skuteczności prowadzonych przez siebie sesji coachingowych i zastosowanych narzędziach. Natomiast Krystyna i Tomasz za niezwykle potrzebne uważają uczestnictwo w sesji coachingowej w roli klienta - jest to dla nich forma pracy nad udoskonalaniem swojego stylu prowadzenia coachingów. Dzięki temu badani mogą samodzielnie doświadczyć trudności, jakim podlegają ich klienci, przechodząc proces coachingu, a także stać się bardziej świadomi ich potrzeb i oczekiwań. Ideałem jest więc wypracowanie w sobie nawyku refleksyjnej praktyki i krytycznego, metodycznego podejścia do własnej aktywności (co jest ważne dla wszystkich badanych przeze mnie coachów), tak aby ciągle doskonalić się w swoich umiejętnościach i jednocześnie dzielić się $\mathrm{z}$ innymi coachami wartościowymi doświadczeniami, stając się tym samym nie

\footnotetext{
${ }^{30}$ A. Pyrek, H. Szmidt, Coaching jako profesja. Standardy nauczania i praktyki coachingu, w: P. Smółka (red.), Coaching. Inspiracje z perspektywy nauki, praktyki i klientów, Gliwice 2009, s. 103 .
} 
tylko konsumentami wiedzy, ale także inspiratorami postępu praktyki i nauki coachingu ${ }^{31}$.

Ważne jest spostrzeżenie Mariusza, który jako jedyny mówi wprost, iż mimo wielości firm szkoleniowych oferujących szkolenia z coachingu, tylko część $\mathrm{z}$ nich odnosi się do tego, co jest jego istotą. Temat jest modny i dlatego pod tą samą nazwą sprzedawane są szkolenia $\mathrm{z}$ innych form wspierania rozwoju jednostki. Świadomy celu, jaki chce osiągnąć, coach powinien umieć selekcjonować kwalifikacje, jakie będą dla niego przydatne w pracy. Uwagę tę można odnieść do wypowiedzi Tomasza, w której przedstawia krytyczną refleksję na temat „przeładowania” wiedzą o coachingu zdobytą na szkoleniach. Wskutek nadmiaru informacji badany miał poczucie, że wie mniej, niż oczekiwał. Tomasz zauważa także, że czasopisma branżowe powierzchownie traktują temat coachingu, artykuły nie dostarczają fachowej wiedzy i informacji, nie można ich postrzegać jako naukowego źródła informacji na temat profesji coacha i obszarów jego pracy.

\section{Reprezentacje sieci powiązań: znaczenie wiedzy, umiejętności i wartości w pracy coacha}

Prezentowane wykresy ukazują trzy sieci powiązań przyczynowych pomiędzy badanymi kategoriami w wywiadach coachów Krystyny, Tomasza i Mariusza, odnoszącymi się do problemu badawczego zainteresowanie coachingiem.

Wykres 7. Sieć powiązań wywiadu 1 (Krystyna)

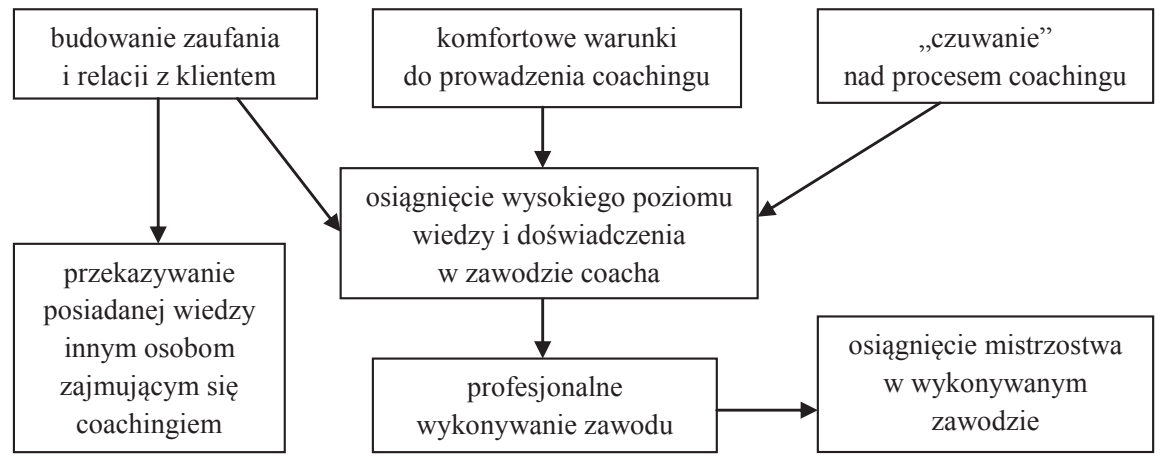

Źródło: badania własne.

${ }^{31}$ P. Smółka, Coaching oparty na dowodach, w: tamże, s. 44-45. 
Nota 7: Krystyna z racji rozległej wiedzy o coachingu jest świadoma, jak niezbędna jest ona do prawidłowego prowadzenia sesji coachingowych, nawiązania relacji z klientem, budowania atmosfery zaufania, aby klient prawidłowo przeszedł proces coachingu. Realizowanie tych składowych pozwala właściwie wykonywać profesję coacha i osiągnąc wysoki poziom profesjonalizmu oraz doświadczenia, co przyczynia się do mistrzowskiego wykonywania swoich zadań zawodowych.

Wykres 8. Sieć powiązań wywiadu 2 (Tomasz)

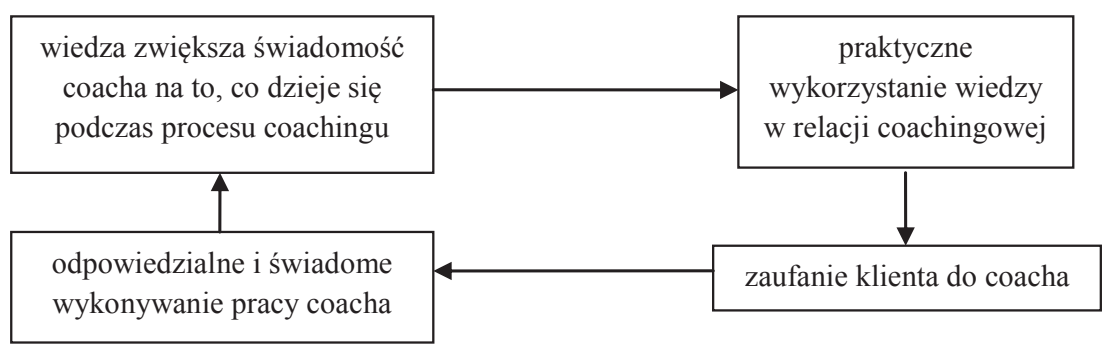

Źródło: badania własne.

Nota 8: Według Tomasza wiedza, jaką posiada coach, powoduje, że zwraca on większą uwagę na to, co dzieje się podczas sesji coachingowej. Wiedza przyczynia się więc do profesjonalnego, świadomego i odpowiedzialnego wykonywania zadań coachingowych, jak zauważa badany. Znaczenie wartości w procesie coachingu odnosi się do zaufania, jakim klient obdarza coacha. Coach, kierując się w swojej pracy wartościami, wie, że nie może zawieść klienta, musi być wobec niego szczery.

Nota 9: Według badanego na kompetencje coacha składa się wiele elementów. Jest to zindywidualizowanie coachingu dla potrzeb danego klienta za sprawą umiejętnego zadawania pytań czy pracy nad zmianą jego przekonań, co pozwoli coachowanemu osiągnąć pozytywną zmianę. Posiadana przez coacha wiedza powoduje, że dysponuje on narzędziami i metodami, które wykorzystuje w pracy z klientem, aby mógł on osiągnąć zamierzone cele, a także dba o ekologię coachingu - zachowanie równowagi we wszystkich aspektach życia klienta, na które wpływ może mieć zmiana, jaką chce on osiągnąć. Wiedza na temat coachingu pozwala także coachowi stworzyć podczas sesji atmosferę otwartości, dyskrecji i bezpośredniej komunikacji między coachem a klientem, co sprzyja zaspokojeniu potrzeb klienta wobec coachingu. 
Wykres 9. Sieć powiązań wywiadu 3 (Mariusz)

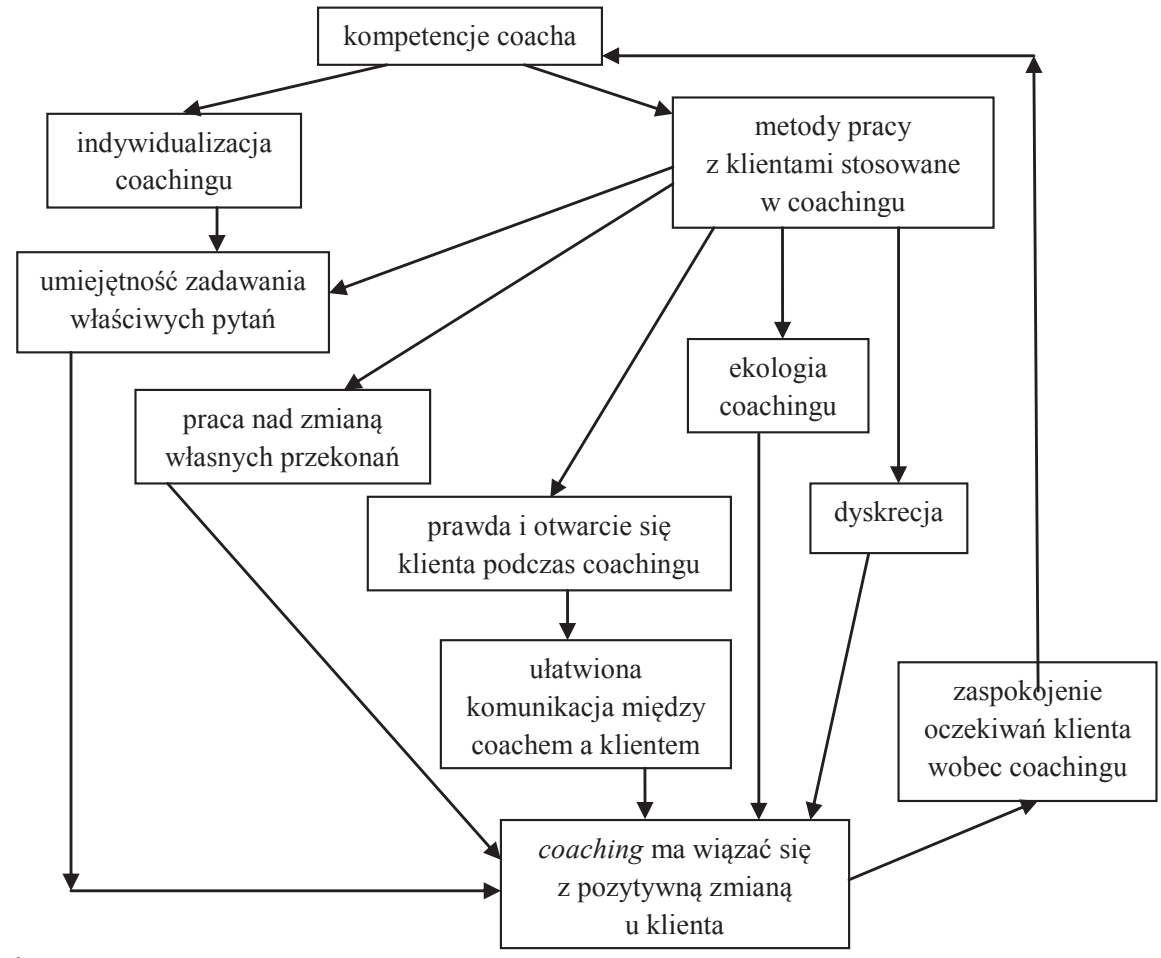

Źródło: badania własne.

W ramach not teoretycznych dotyczących znaczenia wiedzy, umiejętności i wartości w pracy coacha wszyscy badani podkreślają, iż coaching służy przede wszystkim klientowi, wspiera go w realizowaniu osobistej wizji życia lub kariery zawodowej. Dlatego wiedza i umiejętności są tak ważne w tej profesji, a przygotowanie do jej wykonywania prowadzi do rozwinięcia dojrzałości emocjonalnej we wszystkich jej wymiarach: samoświadomości, świadomości innych, kierowania sobą oraz wpływania na innych ${ }^{32}$. Wartości te, ważne dla profesjonalnego prowadzenia sesji coachingowych, są wymieniane przez wszystkich badanych, co świadczy o ich istotności w pracy coacha.

W wypowiedziach Krystyny, Tomasza i Mariusza można zauważyć, że wiedza stanowi według nich podstawę dla prawidłowego prowadzenia i przebiegu sesji coachingowych, nawiązania relacji z klientem, stworzenia atmosfery

${ }^{32}$ A. Pyrek, H. Szmidt, dz. cyt., s. 96. 
sprzyjającej otwartości i zaufania między coachem a klientem. Tomasz zauważa, że coach posiadający rozległą wiedzę na temat coachingu i wykorzystujący ją w praktycznym działaniu, owocującym prawidłowo przeprowadzonymi sesjami z klientem, jest postrzegany jako profesjonalista o wysokich kompetencjach, co jest ważne w środowisku branżowym.

\section{Podsumowanie}

Głównym problemem niniejszego artykułu było odkrycie i opisanie źródeł, z jakich korzystają osoby zainteresowane coachingiem, aby zdobyć wiedzę i umiejętności potrzebne do wykonywania profesji coacha. W celu uzyskania tych informacji przedmiotem poznania uczyniłam narracje badanych pozyskane w drodze wywiadów indywidualnych. Otrzymane dane pozwoliły mi na wyodrębnienie trzech obszarów badawczych, jakimi są: zainteresowanie badanych tematyką coachingu, metody pozyskiwania wiedzy dotyczącej coachingu i sposoby doskonalenia umiejętności z tego obszaru oraz refleksja badanych nad znaczeniem wiedzy, kompetencji i wartości w pracy coacha.

$\mathrm{Z}$ przeanalizowanego materiału badawczego wynika, że zainteresowanie respondentów nową metodą pracy z ludźmi wyniknęło z potrzeby podnoszenia wiedzy i zdobywania nowych umiejętności, które pozwalają stawać się coraz bardziej kompetentnym w wykonywanym zawodzie, bądź było motywowane chęcią osiągnięcia radykalnej zmiany w życiu. Podstawowym źródłem zdobywania wiedzy i umiejętności coachingowych są szkolenia i konferencje - badani korzystają z nich najczęściej. Praktyczne wykorzystanie posiadanej wiedzy oraz lektura literatury fachowej i prasy poświęconej tematyce coachingu jest bardzo istotnym źródłem uczenia się. Ważna dla badanych jest głęboka refleksja i krytyczny stosunek do wykonywanej pracy. Widoczne jest to w wypowiedziach odnoszących się do znaczenia wiedzy, umiejętności i wartości w pracy coacha, w których badani odwołują się do swojej pracy, posiadanej wiedzy i doświadczenia. Największe znaczenie badani przypisują wiedzy, która gwarantuje znajomość narzędzi i metod wykorzystywanych podczas spotkań z klientem, a także pozwalającej zachować pełną kontrolę nad przebiegiem procesu coachingu.

Na podstawie wyników badań można stwierdzić, że najbardziej popularną formą jest edukacja pozaformalna oraz nieformalna. Wymienione rodzaje edukacji dorosłych charakteryzuje to, że odbywają się poza formalnym systemem oświatowym, są podejmowane samodzielnie przez osoby chcące zdobyć szerszą wiedzę z danego obszaru, a często mają charakter nieuświadomionego 
procesu pozyskiwania informacji. Jednak w środowisku branżowym coachingu rysują się tendencje do uzyskiwania formalnych kwalifikacji z zakresu coachingu na poziomie uniwersalnym, np. przez udział w studiach podyplomowych. Stwarzają one możliwość do poznania kanonu wiedzy, metod i dobrych praktyk coachingu oraz do wytrenowania umiejętności niezbędnych w samodzielnym prowadzeniu sesji coachingowych. Pomyślne odbycie takich studiów (zakończone teoretycznym oraz praktycznym egzaminem obejmującym także superwizję sesji coachingu prowadzonych przez studenta) powinno otworzyć ich absolwentom drogę do wykonywania zawodu ${ }^{33}$.

Należy jednak pamiętać, iż zrealizowane badania dotyczą indywidualnych doświadczeń, nie można ich odnieść do szerszej populacji. Wyprowadzone wnioski można rozpatrywać wyłącznie w kontekście trojga badanych coachów, daje to jednak obraz pewnego mechanizmu rozwoju profesji coacha.

$\mathrm{Z}$ literatury przedmiotu oraz wypowiedzi badanych coachów wynika, że coaching, jako obszar praktyki zawodowej, znajduje się na wczesnym etapie profesjonalizacji, wciąż jest zjawiskiem rynkowym, oznacza to, że każdy może zostać coachem i świadczyć usługi coachingowe. Dlatego jednym z wyzwań, jakie stoją przed coachami, jest zwiększenie własnej wiarygodności i udokumentowanie efektywności swojej praktyki. Wiąże się to z potrzebą rzeczowej, twórczej, ale także sceptycznej refleksji nad podstawowymi teoretycznymi i empirycznymi dowodami skuteczności oraz sprawdzonymi i godnymi upowszechnienia praktykami coachingu ${ }^{34}$. Niniejszy artykuł ukazuje nowy obszar działania dla edukacji, która ma sprostać oczekiwaniom ludzi chcących doskonalić swoje kompetencje w zakresie wykonywanego zawodu.

\section{Bibliografia}

Czarkowska L. D., Profesjonalizm i proces profesjonalizacji w coachingu, „Coaching Review" 2010, nr 1.

Day Ch., Rozwój zawodowy nauczyciela, Gdańsk 2004.

Dębska E., Mentor, coach, facylitator - trzy role doradcy zawodu, „Edukacja Dorosłych” 2010, nr 1.

Dubas E., Świtalski W. (red.), Uczenie się z (własnej) biografii, Łódź 2011.

${ }^{33}$ P. Smółka, Coaching oparty na dowodach, s. 25.

${ }^{34}$ Tamże, s. 23. 
Filipowicz G., Zarzadzanie kompetencjami zawodowymi, Warszawa 2004.

Kargul J., Obszary pozaformalnej i nieformalnej edukacji dorostych, Wrocław 2001.

Kruszewski Z. P. (red.), Możliwości i ograniczenia kształcenia ustawicznego, Płock 2008.

Lalak D., Życie jako biografia. Podejście biograficzne w perspektywie pedagogicznej, Warszawa 2010.

Lowe J., Rozwój oświaty dorostych, Warszawa 1982.

Malewski M., Modele pracy edukacyjnej z ludźmi dorostymi, w: E. Przybylska (red.), Andragogiczne wątki, poszukiwania, fascynacje, Toruń 2001.

Malewski M., Od nauczania do uczenia się. O paradygmatycznej zmianie $w$ andragogice, Wrocław 2010.

Pachociński R., Andragogika w ujęciu międzynarodowym, Warszawa 1998.

Piorunek M., Bieg życia zawodowego. Kontekst transformacji kulturowych, Poznań 2009.

Półturzycki J., Kierunki i tendencje przemian współczesnej edukacji dorosłych, w: J. Sarana (red.), Edukacja dorostych. Teoria i praktyka w okresie przemian, Lublin 2000.

Rubacha K., Metodologia badań nad edukacją, Warszawa 2008.

Smółka P. (red.), Coaching. Inspiracje z perspektywy nauki, praktyki i klientów, Gliwice 2009.

Szmidt K. J. (red.), Metody pedagogicznych badań nad twórczościa, Łódź 2009.

Thorpe S., Clifford J., The Coaching Handbook: An Action Kit for Trainers and Managers, London 2003.

Zubrzycka- Nowak M., Rybczyńska K., Monostori S., Czym (nie) jest coaching, Sopot 2010.

\section{Netografia}

http://www.pdf.net/Files/Dublin\%20Declaration\%20on\%20Coaching.pdf (dostęp: 17.02.2011).

http://www.pifs.org.pl/pliki/raport\%20szkola\%20dla\%20coacha.pdf (dostęp: 17.02.2011). 


\section{Sources and the meaning of coach's competences. Case studies}

\section{Summary}

To exemplify subjects which I bring up I explain what coaching is and what is important for individual personal development. Then I present the results of my research. Analyzed material shows that respondents' interest in new method of working with people has arose from the need for raising awareness and acquiring new skills, which enable to become more competent in their profession, or was motivated by the desire for a radical change in their life. The sources of knowledge and coaching skills are training courses and conferences, practical use of knowledge and reading professional literature and coaching press. Reflection and critical attitude to their job are important for tested people. Respondents father the highest value of information on coach proper performance. Practicing coaches' biographical narratives, where they have been describing how to acquire needed coaching skills, were made the subject of my research. I used the biographical research method and also a technique of partly directed personal narrative interview. Respondents had reconstructed their experiences related to the acquisition of new skills and knowledge in their own individual way.

Keywords: coach, coaching, biography, biographical method. 